\title{
Keluarga: Pendekatan Teoritis Terhadap Keterlibatan Orangtua dalam Pendidikan Anak Usia Dini
}

\section{Dwi Hardiyanti}

Prodi Pendidikan Guru Pendidikan Anak Usia Dini, Fakultas Keguruan dan Ilmu Pendidikan, Universitas IVET, Indonesia

\section{Info Articles}

Sejarah Artikel:

Disubmit 6 Maret 2021

Direvisi 10 April 2021

Disetujui 3 Mei 2021

\section{Keywords:}

Children, Early Childhood

Education; Family

involvement; Support

system

\begin{abstract}
Abstrak
Pendidikan harus dianggap sebagai program komprehensif yang mencakup siswa, orang tua, guru, personel pendukung, dan anggota masyarakat. Keterlibatan orang tua dalam pendidikan merupakan komponen penting untuk keberhasilan semua anak. Keterlibatan orang tua selama prasekolah telah dikaitkan dengan keterampilan literasi yang lebih kuat, keterampilan matematika, keterampilan sosial yang berkembang dengan baik, dan sikap positif terhadap sekolah (Arnold, Zeljo, Doctoroff, \& Ortiff, 2008; Powell, Son, File, \& San Juan, 2010). Dimensi keterlibatan orangtua dapat dibedakan menjadi enam dimensi yaitu mengasuh anak, berkomunikasi, menjadi sukarelawan atau mendukung sekolah, belajar dukungan orang tua di rumah, pengambilan keputusan, dan bekerja sama komunitas. Hal lain yang perlu ditekankan adalah keterlibatan orangtua dalam pendidikan anak usia dini (PAUD) tidak akan optimal tanpa adanya dukungan dari guru atau sekolah
\end{abstract}

Abstract

Education should be considered a comprehensive program that includes students, parents, teachers, support personnel, and community members. Parental involvement in education is an important component for the success of all children. Parental involvement during preschool has been associated with stronger literacy skills, math skills, well-developed social skills, and positive attitudes toward school (Arnold, Zeljo, Doctoroff, \& Ortiff, 2008; Powell, Son, File, \& San Juan. , 2010). The dimensions of parental involvement can be divided into six dimensions, namely caring for children, communicating, volunteering or supporting schools, learning parental support at home, making decisions, and working together in the community. Another thing that needs to be emphasized is that the involvement of parents in early childhood education will not be optimal without the support of teachers or schools.

${ }^{凶}$ Alamat Korespondensi:

E-mail: dwihardiyanti@ymail.com
p-ISSN XXXX-XXX

e-ISSN XXXX-XXX 


\section{PENDAHULUAN}

Keragaman, dalam berbagai bentuknya, termasuk sosial ekonomi, budaya, dan kemampuan, menambah kekayaan dan semangat yang luar biasa pada budaya dan sekolah masyarakat kita. Keragaman ini juga berpengaruh pada bagaimana keluarga, terutama orangtua melalui pola asuhnya membentuk pribadi kita masing-masing. Dalam situasi pandemik saat ini, situasi yang tidak pernah terbayangkan sebelumnya, dimana anak-anak mulai bersekolah dari rumah atau School From Home $(\mathrm{SFH})$, kiranya perlu dipikirkan kembali bahwa memang keterlibatan orangtua di dalam pendidikan dan intervensi terutama pada anak usia dini (AUD) memegang peranan yang penting dalam menunjang kesuksesan pendidikan. Tentu yang dimaksud bukan hanya pendidikan secara akademis tetapi juga pendidikan moral dan etika yang tentunya akan sangat berperan dalam kehidupan anak tersebut kelak.

Kondisi pandemik ini sedikit banyak mulai membuka mata para orangtua bahwa apa yang para tenaga pendidik alami dalam proses mengajar selama di sekolah ini tidak mudah. Banyak hal yang harus dipertimbangkan dan dipersiapkan dalam mendidik dan mengajar anak-anak dan para siswa ini. Situasi ini memaksa orangtua untuk meningkatkan kemampuan parenting mereka karena saat ini para orangtua berhadapan dan berinteraksi lebih banyak dengan anak-anak mereka dibanding sebelum masa pandemik. Lalu, bagaimana keluarga dapat mengambil porsi lebih dari para pengajar dengan tetap berfokus pada pengembangan anak? Salah satu hal yang dapat dilakukan adalah dengan memperdalam kemampuan parenting yang pada tingkat anak usia dini (AUD) menjadi sangat penting karena pada masa inilah anak-anak tersebut membangun dirinya, membentuk dirinya, akan menjadi orang dewasa seperti apakah mereka nantinya.

Semua itu sekarang terletak penuh pada tangan para orangtua, hal yang lebih berat tentu saja tidak hanya terkait dengan pendidikan akademis maupun non-akademis, tetapi juga pada pengembangan sosial, emosional dan pengembangan kepribadian serta kemampuan anak. Hal-hal ini tentunya tidak pernah terlintas dalam pikiran orangtua terutama orangtua yang keduanya bekerja, tetapi sekali lagi, dengan kondisi pandemik ini, semua tatanan berubah. Dan tentu, anak-anak terutama anak usia dini (AUD) terdampak pula. Anak usia dini (AUD) menjadi fokus dalam artikel ini karena kelompok inilah yang dapat diasumsikan paling rentan terdampak negatif dari kondisi bersekolah dari rumah. Hal ini dikarenakan kurikulum pembelajaran pada tingkat ini lebih berfokus kepada tugas perkembangan setiap anak ketimbang pembelajaran akademik. Dan tentu sesuai prinsip dari psikologi perkembangan, tumbuh kembang setiap anak tidak berada dalam kecepatan yang sama sehingga penilaian terhadap kemampuan tumbuh kembang anak harus benar-benar secara holistik sehingga dapat menggambarkan kondisi anak seutuhnya.

Pencapaian tugas perkembangan ini harus didukung oleh pemahaman dari orangtua bahwa setiap tahapan perkembangan anak memiliki tugas perkembangan yang mungkin nampak sepele/mudah bagi orang dewasa tetapi sebenarnya menantang bagi anak usia dini. Kebijakan bersekolah dari rumah di masa pandemik ini, mendorong orangtua untuk tidak hanya terlibat dalam pendidikan anak tetapi juga sebagai pengajar utama. Kebanyakan dari tugas perkembangan anak usia dini banyak melibatkan interaksi dengan lingkungan sekitar. Bermain bersama teman, dapat menjadi salah satu seting lingkungan untuk merangsang perkembangan bahasa, sosial dan emosional anak usia dini. Namun, dengan kondisi pandemik, orangtua dan keluarga lah yang harus menjadi teman bermain bagi anak usia dini sehingga kebutuhan perkembangannya dapat terpenuhi.

Dengan banyaknya dorongan untuk lebih terlibat dalam pendidikan anak, kondisi pandemik ini adalah salah satu kondisi yang memungkinkan orangtua untuk benar-benar berperan aktif dalam pendidikan anak mereka. Keterlibatan orang tua selama prasekolah telah dikaitkan dengan keterampilan literasi yang lebih kuat, keterampilan matematika, keterampilan sosial yang berkembang dengan baik, dan sikap positif terhadap sekolah (Arnold, Zeljo, Doctoroff, \& Ortiff, 2008; Powell, Son, File, \& San Juan, 2010). Namun keterlibatan orangtua dalam pendidikan bukanlah hal yang mudah mengingat semakin banyak anak yang dibesarkan oleh orang tua tunggal, 
kakek nenek, dan orang tua angkat, atau di mana kedua orang tua di rumah harus bekerja (Stacer \& Perrucci, 2013).

Situasi pandemik ini sudah jelas memberikan tantangan tersendiri dimana situasinya dapat diibaratkan sebagai pisau bermata dua. Di satu sisi, orangtua lebih banyak dirumah sehingga dapat lebih meluangkan waktu untuk bersama dengan anak-anak mereka tetapi dengan kondisi ekonomi yang semakin sulit tentu tidak dapat dipungkiri akan meningkatkan level stress orangtua. Sedikit penjabaran diatas diharapkan dapat sedikit menimbulkan pertanyaan dalam pikiran kita, apakah kita sebagai orangtua, sebagai keluarga sudah terlibat dalam memastikan pendidikan anak? Dan apakah keterlibatan tersebut benar memberikan tantangan bagi anak-anak untuk berkembang ke arah positif atau justru ke arah negatif dengan terlalu banyak pemberian bantuan dari orangtua?

\section{PENDEKATAN TEORITIS}

\section{Keterlibatan Orangtua}

Tahun-tahun awal pra-sekolah untuk anak usia dini (AUD) merupakan peluang penting untuk pengembangan keterlibatan orangtua dalam pendidikan awal anak usia dini (AUD) karena keterlibatan aktif orang tua dalam pembelajaran anak-anak mereka telah terbukti meningkatkan hasil akademik, perilaku, dan sosial anak. (Marcon, 1999; Powell, Sone, File, San Juan, 2010; Senechal,2006). Secara khusus, keterlibatan orangtua memfasilitasi perkembangan anak dari keterampilan pra-literasi seperti kesadaran fonologis dan pengetahuan nama huruf (Powell, Sone, File, San Juan, 2010).

Pemangku kepentingan utama yang terlibat dalam menyediakan pendidikan berkualitas untuk AUD adalah orang tua, guru, pengelola sekolah, dan masyarakat. Proses ini berkembang di antara para pemangku kepentingan utama untuk terlibat secara aktif selama pendidikan anak. Beberapa penelitian terdahulu membuktikan bahwa koneksi yang kuat dan suportif antara keluarga dan lingkungan sekolah mendukung pembelajaran anak-anak dan mengurangi masalah perilaku (Fiese, Eckert, \& Spagnola, 2006; McWayne, Hampton, Fantuzzo, Cohen, \& Sekino, 2004; Zellman \& Perlman, 2006). Penelitian lain dari Morrison, Storey, dan Zhang (2011), juga menunjukkan bahwa ada korelasi positif antara keterlibatan keluarga dalam pendidikan anak dan prestasi anak. Menurut Grace, Jethro, \& Aina (2012) dan Weldon (2011), keterlibatan positif orang tua menentukan masa depan anak; "Ketika sekolah dan keluarga bekerja sama untuk mendukung pembelajaran, anak-anak cenderung berhasil tidak hanya di sekolah tetapi sepanjang hidup" (Grace, Jethro, \& Aina, 2012).

Sheldon (2002) menggambarkan keterlibatan orang tua sebagai "interaksi orang tua-anak pada kegiatan belajar yang berhubungan dengan sekolah atau lainnya dan mewakili investasi langsung dari sumber daya orang tua dalam dirinya pendidikan anak. Menurut Wong (2012), "Keterlibatan orang tua adalah sejauh mana orang tua tertarik, mengetahui tentang, dan mau berperan aktif dalam kegiatan sehari-hari anak-anaknya. Pendapat Epstein biasanya digunakan dalam penelitian pendidikan dan memberikan panduan untuk menyoroti elemen yang mungkin kurang dari keterlibatan orang tua (Fishman \& Nickerson, 2015; Grant \& Ray, 2018). Epstein (1995, 1996, 2001, 2005, 2010 \& 2011) mengklasifikasikan keterlibatan orang tua menjadi enam dimensi: mengasuh anak, berkomunikasi, menjadi sukarelawan atau mendukung sekolah, belajar dukungan orang tua di rumah, pengambilan keputusan, dan bekerja sama komunitas. Menjadi terlibat dalam pendidikan anak bukan berarti tidak ada halangan yang dapat menghambat tingkat keterlibatan orangtua dalam pendidikan anak. Teori Epstein mendukung struktur keterlibatan orang tua dan dapat digunakan untuk bertahan terhadap hambatan yang mungkin terjadi, seperti demografi, perbedaan budaya, dan hambatan bahasa, orang tua yang kurang percaya diri, dan status ekonomi (Al-Dababneh, 2017; Egalite, 2016; O'Donoghue, 2014). Banyak dari hambatan ini mungkin ada di antara berbagai jenis keterlibatan orang tua dalam pendidikan anak usia dini tetapi dengan panduan dari enam dimensi teri Epstein, segala hambatan tersebut diharapkan dapat diatasi dalam setiap jenjang pendidikan. 


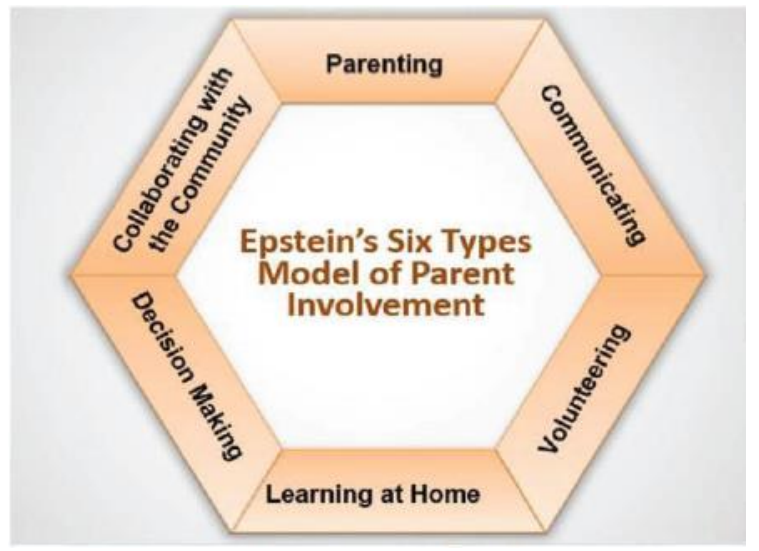

Gambar 1. Dimensi Keterlibatan Orangtua (Epstein, dkk.,2018)

Waktu yang orang tua mampu habiskan dengan anak-anak juga memiliki dampak emosional positif yang memberi anak-anak mereka model keterampilan sosial dan budaya yang baik. Sikap yang lebih positif terhadap sekolah dan akademisi juga merupakan hasil dari peningkatan keterlibatan orang tua. Dampak positif lain dari keterlibatan orangtua adalah pengembangan kemampuan bahasa anak, terutama bahasa kedua. Di era sekarang ini, orang tua lebih fasih dengan makna mempelajari bahasa lain pada tahap awal kehidupan anak-anak mereka. Oleh karena itu, orang tua berkeinginan untuk memberikan pendidikan sekolah yang lebih baik kepada anaknya dengan memilih sekolah yang menawarkan kurikulum dalam lingkungan dua bahasa. Di banyak bagian dunia, anak-anak dikirim ke taman kanak-kanak dua bahasa pada usia tiga tahun. Hossenpour dkk. (2015) menyoroti bahwa minat orang tua pada anak-anak mereka belajar bahasa kedua pada usia dini meningkat.

Dengan banyaknya penelitian yang menunjukkan dampak positif dari keterlibatan orangtua terhadap pendidikan anak, apa sebenarnya yang dimaksud keterlibatan orangtua? Apakah bertanya tentang kegiatan anak di sekolah adalah salah satu bentuk keterlibatan orangtua? Atau terlibat dalam setiap kegiatan di sekolah anak adalah bentuk keterlibatan yang dimaksud dan yang dapat membawa dampak positif bagi pendidikan dan kehidupan anak-anak kelak? Keterlibatan orang tua dan keluarga didefinisikan dalam berbagai cara di seluruh literatur. Orang atau organisasi yang memberikan arti pada istilah tersebut tampaknya menjadi faktor dalam berbagai definisi (Anderson \& Minke, 2007). Keterlibatan orang tua juga dapat didefinisikan sebagai lingkungan tempat keterlibatan itu terjadi (Stephaniak, 2015,h.29): di rumah atau di sekolah. Keterlibatan orang tua di sekolah dapat termasuk menjadi sukarelawan di kelas, berpartisipasi dalam acara sekolah seperti acara sosial atau konferensi orang tua-guru, keterlibatan dalam organisasi orang tua-guru, atau kunjungan lapangan kelas. Keterlibatan orang tua di rumah dapat mencakup membacakan untuk anak, terlibat dalam kegiatan yang sesuai dengan perkembangan anak dengan anak, membantu anak dengan pekerjaan rumah, atau sekadar berbicara dengan anak tentang pengalamannya di sekolah setiap hari.

Sebelumnya sudah dibahas tentang keterlibatan orangtua dalam bentuk positif, lalu apakah ada bentuk keterlibatan orangtua yang negatif? Beberapa hal yang seringkali terlupa, salah satunya pada saat orangtua membantu anak dalam mengerjakan tugas mereka adalah, orangtua harus menempatkan diri pada posisi yang sama dengan guru mereka di sekolah atau di TPA, yaitu sebagai pembimbing. Seringkali dan bukan hal yang rahasia bahwa selama periode sekolah dirumah, banyak anak - anak termasuk anak usia dini yang mencapai perkembangan akademis dan non-akademis yang sangat meningkat, termasuk juga pada anak usia dini. Anak usia dini yang sebelumnya belum dapat menulis, menjadi dapat menulis. Perkembangan yang terlalu signifikan ini tentu harus menjadi perhatian lebih bagi guru ataupun sekolah, karena hal terakhir yang kita inginkan adalah bahwa orangtua atau keluarga yang mengambil alih tugas sekolah anak. 


\section{HASIL DAN PEMBAHASAN}

Orangtua, keluarga dan pendidikan anak merupakan tiga hal yang akan selalu terkait. Orangtua memainkan peranan penting dalam membentuk anak - anak bahkan sejak dalam kandungan, pengaruh orangtua terhadap anak-anak sudah banyak dibuktikan oleh penelitian penelitian terdahulu. Sampai anak-anak tersebut masuk kedalam sistem pendidikan formal atau sekolah, pengaruh terbesar dalam pembentukan diri mereka tetap orangtua dan keluarga. Pendidikan anak usia dini (PAUD) seringkali merupakan langkah awal dalam penentu keterlibatan orangtua. Seberapa jauh orangtua mau terlibat aktif dalam pendidikan anaknya dan benar-benar memahami bahwa proses pendidikan anak tidaklah selesai sewaktu anak - anak mereka pulang dari sekolah. Proses pembelajaran tetap akan berlangsung baik itu di rumah maupun di sekolah. Orangtua dan guru, harus terlibat aktif dalam komunikasi dan koordinasi untuk memastikan hasil yang optimal pada anak.

Dalam kerangka pendidikan anak usia dini (PAUD) dimana pencapaian seorang anak atau siswa bukanlah selalu berbentuk pencapaian akademik, kerjasama antara orangtua dan guru, serta keterlibatan orangtua dalam pendidikan itu sendiri akan membawa dampak besar bagi perkembangan anak. Teori Ekologi dari Bronfenbrenner (1979), merupakan salah satu teori yang dapat menggambarkan bagaimana orangtua, keluarga, guru, dan sekolah berperan dalam pengembangan diri anak. Bronfenbrenner (1979) mengidentifikasi lima sistem lingkungan di mana seorang individu dipengaruhi oleh: sistem mikro, mesosystem, ekosistem, sistem makro, dan kronosistem, dimana sistem mikro mencakup keluarga, lingkungan, dan kolega individu, sedangkan mesosystem adalah hubungan dan koneksi antara lingkungan sistem mikro dan kolega, sedangkan mesosystem adalah hubungan dan koneksi antara mikrosistem, lingkungan, dan kolega, sedangkan mesosystem adalah hubungan dan koneksi antar mikrosistem.

Misalnya, anak-anak dari rumah yang terlantar atau dilecehkan mungkin sulit mengembangkan hubungan dengan orang dewasa di sekolah mereka. Ekosistem adalah dampak dari sistem yang tidak berhubungan langsung dengan individu, tetapi memengaruhi individu. Contoh ekosistem adalah tempat kerja ibu yang berdampak pada anak. Sistem makro adalah budaya yang di dalamnya individu kehidupan. Terakhir, kronosistem adalah pola peristiwa lingkungan dan transisi selama perjalanan hidup seseorang. Penggambaran tentang teori ekologi ini akan diperkuat juga oleh teori dari Epstein, dimana dalam teori Epstein, keterlibatan orangtua dalam pendidikan anak terbagi menjadi enam dimensi yaitu mengklasifikasikan keterlibatan orang tua menjadi enam dimensi: mengasuh anak, berkomunikasi, menjadi sukarelawan atau mendukung sekolah, belajar dukungan orang tua di rumah, pengambilan keputusan, dan bekerja sama komunitas (Epstein, 1995, $1996,2001,2005,2010 \& 2011)$.

Sehingga perilaku orangtua sesederhana menanyakan bagaimana hari yang dilalui oleh anak, sudah dapat digolongkan ke dalam bentuk keterlibatan orangtua. Keterlibatan orangtua ini tidak dapat terbangun dalam waktu yang singkat tetapi dalam waktu yang lama dan membutuhkan konsistensi dari orangtua, keluarga dan juga guru. Guru atau sekolah tetap berperan karena seringkali kurangnya keterlibatan orangtua bukan disebabkan orangtua tidak mau terlibat tetapi juga karena adanya hambatan dari guru itu sendiri maupun dari value budaya. Sebagai contoh, dalam beberapa budaya, guru dianggap sebagai pihak yang sangat memahami bagaimana pendidikan terhadap anak harus diberikan, sehingga tidaklah sopan jika orangtua ikut campur dalam pembelajaran yang diajarkan oleh guru. 


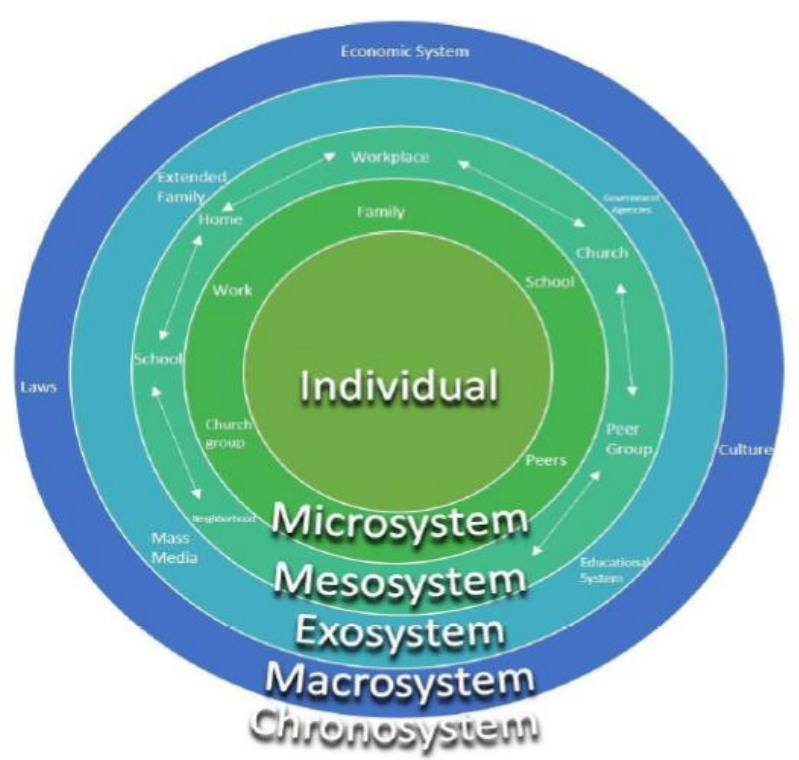

Gambar 2. Teori Model Ekologi Bronfenbenner (1979).

Dengan banyaknya teori yang membahas tentang keterlibatan orangtua, sudah seharusnya para orangtua memiliki gambaran yang jelas, terutama di masa pandemic ini dimana guru dan sekolah sekarang tidak banyak berperan dalam pendidikan anak kecuali menyiapkan kurikulum. Porsi keterlibatan yang paling besar sekarang diharapkan datang dari orangtua dan keluarga. Namun, terlepas dari semua model saat ini dan ide-ide dasar untuk keterlibatan orang tua, serta pengetahuan tentang upaya yang gagal, tetap ada ketidaksesuaian dan hambatan yang dihadapi orang tua ketika mencoba untuk terlibat dalam pendidikan anak mereka. Hambatan yang mungkin terjadi, seperti demografi, perbedaan budaya, dan hambatan bahasa, orang tua yang kurang percaya diri, dan status ekonomi (Al-Dababneh, 2017; Egalite, 2016; O'Donoghue, 2014).

Desimone (1999) menemukan perbedaan dalam tingkat keterlibatan orang tua di semua ras, etnis, dan tingkat pendapatan keluarga. McDermott dan Rothenberg (2000) memperkuat sentimen ini, karena mereka menemukan guru di lingkungan perkotaan memiliki ekspektasi komunikasi yang sama untuk keluarga berpenghasilan rendah seperti yang mereka lakukan pada keluarga kelas menengah yang memiliki akses telepon yang lebih baik untuk bertanya, pertanyaan dan transportasi untuk mengunjungi sekolah. Turney dan Kao (2009) juga mencatat bahwa orang tua di Asia lah yang mengalami hambatan terbesar terkait dengan keterlibatan orang tua. Namun, tidak hanya ras atau etnis yang berperan dalam hambatan yang dihadapi orang tua.

Struktur keluarga juga berperan, karena Arnold, Zeljo, Doctoroff, Otiz (2008) menemukan bahwa orang tua tunggal cenderung tidak terlibat dalam pendidikan anak mereka; terlebih lagi, orang tua tunggal yang mengalami depresi. Referensi teori yang ada tentang keterlibatan orang tua cukup memberikan banyak saran dan contoh untuk menjelaskan masalah kurangnya pemanfaatan dan kurangnya partisipasi ini (Alameda- Lawson, Lawson, \& Lawson, 2010; Bruckman \& Blanton, 2003; Gonzalez-DeHass \& Willems, 2005; McDermott \& Rothenberg, 2000; Walsh, 2010). Gonzalez-DeHass dan Willems (2005) memberikan alasan khusus untuk konflik tersebut dan kurangnya pemanfaatan keterlibatan orang tua. Alasan tersebut antara lain orang tua kurang percaya diri untuk terlibat, guru tidak menghargai keterlibatan orang tua, anggapan guru tentang kemampuan dan tingkat keterampilan orang tua, kendala waktu, sudut pandang yang berlawanan tentang metode keterlibatan orang tua, kebingungan peran orang tua dalam pendidikan anak mereka, dan kebutuhan untuk persiapan dan dukungan administratif untuk guru (Gonzalez-DeHass \& Willems, 2005). 


\section{SIMPULAN}

Berdasarkan penjelasan berbagai teori dan hasil penelitian diatas, dapat disimpulkan betapa pentingnya keterlibatan orangtua terutama dalam pendidikan pada anak usia dini (AUD). Bukan hanya karena pada usia ini, anak-anak membentuk pemahamannya terhadap dunia tetapi juga karena pendidikan pada anak usia dini tidaklah didominasi dengan pembelajaran akademis yang selalu memiliki nilai pasti, benar dan salah. Pendidikan pada anak usia dini (AUD) lebih condong ke arah pendidikan non-akademis dimana pemahaman anak terhadap konstruk sosial yang berlaku di masyarakat lebih ditekankan dibanding pencapaian akademisnya. Bagaimana mereka belajar berbagi dengan temannya, belajar membagi waktu, belajar kedisiplinan, melatih kemampuan bahasa dan matematika awal akan lebih dari hanya sekedar benar atau salah.

Hal-hal yang sekiranya perlu diperhatikan dalam keterlibatan orangtua dalam pendidikan anak usia dini adalah, pertama, komunikasi antara orangtua dan guru harus sudah terjalin dengan baik sehingga hambatan yang seringkali muncul seperti kurangnya penghargaan yang diberikan guru pada usaha yang dilakukan orangtua tidak tejadi. Kedua, orangtua juga harus memiliki kemampuan untuk menahan diri terutama jika hal tersebut terkait dengan penyelesaian tugas sekolah anak. Perspektif yang perlu ditanamkan adalah, anak usia dini (AUD) hanya perlu menyelesaikan tugas yang diberikan dari guru, nilai bukanlah hal yang menjadi tujuan utama karena seringkali tugas dalam level pendidikan anak usia dini (PAUD) bertujuan untuk memberi kesempatan anak berkembang sesuai potensinya atau melatih kemampuan yang dibutuhkan dalam jenjang pendidikan selanjutnya. Jika hal-hal tersebut dapat benar-benar dijaga dan diimplementasikan dalam sistem pendidikan anak usia dini, sentiment positif terhadap anak-anak generasi penerus bangsa ini akan berkembang secara optimal akan semakin muncul.

\section{DAFTAR PUSTAKA}

Alameda-Lawson, T., Lawson, M.A., Lawson, H.A. (2010). Social worker's roles in facilitating the collective involvement of low-income, culturally diverse parents in an elementary school. Children \& Schools, 32(3), 172-182.

Al-Dababneh, K.A. (2017). Barriers preventing parental involvement in mainstream education of children with specific learning disabilities: parent perspectives. European Journal of Special needs, Vol. 33(5), 615-630.

Anderson, K. J., \& Minke, K. M. (2007). Parent involvement in education: Toward an understanding of parents' decision making. The Journal of Educational Research, 100(5), 311323,328 .

Arnold, D. H., Zeljo, A., Doctoroff, G. L., \& Ortiz, C. (2008). Parent involvement in preschool: Predictors and the relation of involvement to pre-literacy development. The School Psychology Review, 37(1), 74-90.

Bronfenbrenner, U. (1979). The ecology of human development: Experiments by nature and design. Cambridge, MA, Harvard University Press.

Bruckman, M., \& Blanton P.W. (2003) Welfare to work single mother's perspectives on parent involvement in Head Start: Implications for parent-teacher collaboration. Early Childhood Education Journal 30(3), 145-150.

Desimone, L. (1999). Linking parent involvement with student achievement: Do race and income matter? The Journal of Education Research, 93(1), 11-30.

Egalite, A. J. (2016). How family background influences student achievement: can schools narrow the gap? Education Next, 16(2), 70-79.

Epstein, J. L. (1995). School/family/community partnerships. Phi Delta Kappan, 76(9), 701-712. 
Epstein, J. L. (1996). Perspectives and previews on research and policy for school, family, and community partnerships. In A. Booth and J. F. Dunn (Eds.), Family-school links: how do they affect educational outcomes? (pp. 209-246). Mahwah,NJ: Erlbaum.

Epstein, J. L. (2001). School, family, and community partnerships: Preparing educators and improving schools. Boulder, CO: Westview Press.

Epstein, J. L. (2005). Attainable goals? The spirit and letter of the no child left behind act on parental involvement. Sociology of Education, 78(2), 179-182.

Epstein, J. L. (2010). School, family, and community partnerships: Preparing educators and improving schools. Boulder, CO, USA: Westview Press.

Epstein, J. L. (2011). School, family, and community partnerships: Preparing educators and improving schools (2nd ed.). Philadelphia, PA: Westview Press.

Fantuzzo, J., Tighe, E., \& Childs, S. (2000). Family involvement questionnaire: A

multivariate assessment of family participation in early childhood education. Journal of Educational Psychology, 92(2), 367 - 376.

Epstein, J. L., Sanders, M. G., Sheldon, S. B., Simon, B. S., Salinas, K. C., Jansorn, N. R., ... \& Hutchins, D. J. (2018). School, family, and community partnerships: Your handbook for action. Corwin Press. Inc.

Fiese, B., Eckert, T., \& Spagnola, M. (2006). Family context in early childhood: A look at practices and beliefs that promote early learning In B. Spodek \& O. Saracho (Eds.), Handbook of Research on the Education of Young Children, 2 Edition (pp. 393 -409). New Jersey: Lawrence Erlbaum Associates. 